\title{
Common carp - still unused potential
}

Sterniša ${ }^{1}$, M., J. Mraz $^{2}$, S. Smole Možina ${ }^{1}$

Review

\begin{abstract}
SUMMARY
Carps are the most cultured fish worldwide. Their production is still increasing. Common carp is the third most produced fish species, but in year 2014 only $2.32 \%$ of the total was produced in Europe. Together with trout aquaculture, the production of carp in Europe is the most important one. The majority is tied to aquaculture, only about $10 \%$ is captured. Carp market relies mainly on domestic production. However, trade between countries is still traditionally based on live fish, only a small part presents fresh chilled and frozen fish. In the lowlands without access to the sea, but with a possibility of aquaculture production in ponds, carps represent a good potential as a nutrient source for the local population throughout the year. Consumption of carps is primarily local where the market offers variety of carp meat products. Carp, like other fish, has good nutritional value, with quality and nutritional animal proteins and lipids as well as micronutriens. Despite the favorable content of valuable nutrients, freshwater fish are often overlooked as their source, so there is still space for improvement by transferring more knowledge to the consumers and developing new attractive and innovative products. As an example of good practice, an omega-3 carp trademark is mentioned. It was developed in Czech Republic on the basis of traditional common carp production, but offering consumers a new value-added product.
\end{abstract}

Key words: common carp, aquaculture production, nutritional value, inovative food products

\section{COMMON CARP PRODUCTION}

Cyprinids are the most cultivated fish group worldwide and their production is constantly increasing. Common carp (Cyprinus carpio) aquaculture production reached 4159117 tonnes in 2014, making common carp the third most produced fish species in aquaculture worldwide, right after grass carp (Ctenopharyngodon idellus) and silver carp (Hypophthalmichthys molitrix) with 5537 794 and 4967739 tonnes, respectively (Figure 1) (FAO, 2016). Of these three fish species only common carp is indigenous also to Europe (its Central and Eastern part) apart from Asia. As such common carp presents large freshwater fish indigenous to lowland lakes and rivers with optimal natural conditions in Central and Eastern Europe as well as in Caucasus, and Central and Southeastern Asia (Balon, 1995), where there is abundant vegetation to provide food and shelter.

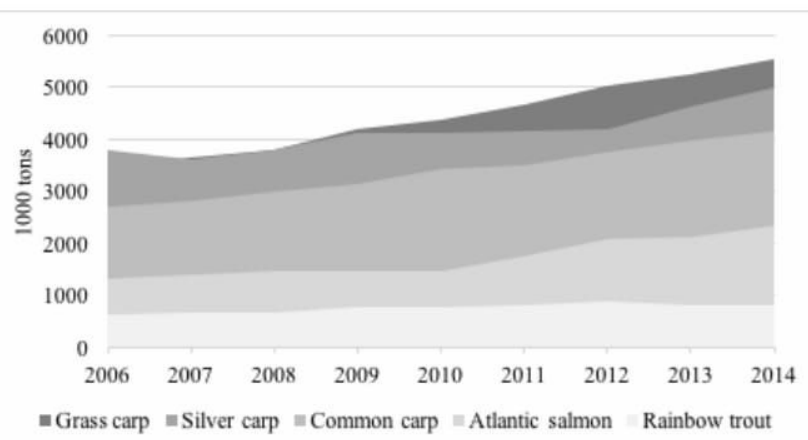

Figure 1: World aquaculture production of grass carp, silver carp, common carp, Atlantic salmon and rainbow trout (FAO, 2016).

Despite the high world aquaculture production of common carp, only $2.32 \%$ was produced in Europe in 2014, with production over 10000 tonnes in Poland, Czech Republic, Ukraine and Hungary (FishstatJ, 2017).

1 Meta Sterniša, DVM; prof. Sonja Smole Možina, PhD; Department of Food Science and Technology, Biotechnical Faculty, University of Ljubljana, Ljubljana, Slovenia 2 Jan Mraz, PhD, ing.; South Bohemian Research Centre of Aquaculture and Biodiversity of Hydrocenoses, Institute of Aquaculture and Protection of Waters, Faculty of Fisheries and Protection of Waters, University of South Bohemia in Česke Budejovice, Česke Budejovice, Czech Republic 
In Table 1, European countries with common carp freshwater aquaculture are arranged in categories according to their production values in year 2014. The main production of carps is localized in Central and Eastern Europe, with Poland, Czech Republic, Hungary and Ukraine contributing over 60\% of production in 2014.

Table 1: European countries (in alphabetical order within the groups) with common carp aquaculture according to their production in 2014 (FishStat, 2017).

\begin{tabular}{|l|l|}
\hline Tonnes & Countries \\
$>20000$ & Poland \\
\hline $10001-20000$ & Czech Republic, Hungary, Ukraine \\
\hline $5001-10000$ & Belarus, Germany, Serbia \\
\hline $1001-5000$ & Bulgaria, Croatia, France, Lithuania, Moldova, Romania \\
\hline $100-1000$ & $\begin{array}{l}\text { Albania, Austria, Bosnia and Herzegovina, Italy, Latvia, } \\
\text { Macedonia, Slovakia, Slovenia, United Kingdom }\end{array}$ \\
\hline$<100$ & Denmark, Estonia, Greece, Spain \\
\hline
\end{tabular}

Carps are one of the main species of European freshwater aquaculture along rainbow trouts, catfish, and eels (FEAP, 2017). European production of rainbow trout has not changed drastically in the last decade. Contrary, common carp production decreased in year 2007 and has not grown ever since (Figure 2). The capture has remained stable with around 10000 tonnes per year, representing approximately $10 \%$ of the annual total carp production.

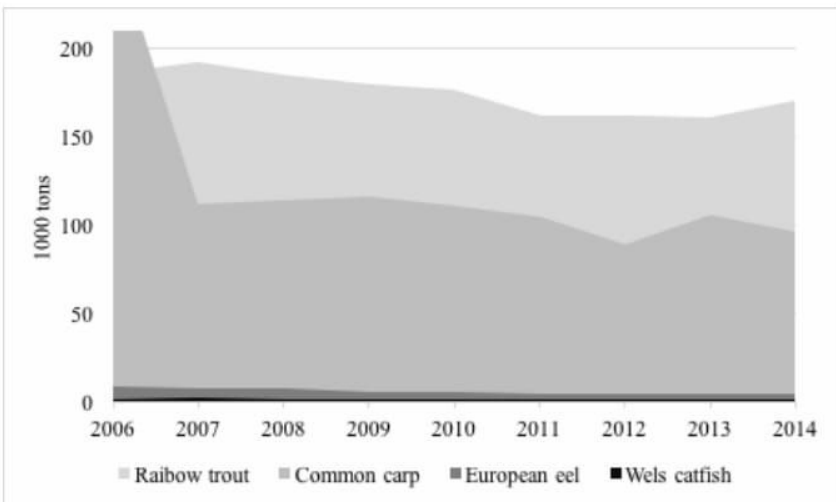

Figure 2: European aquaculture production of rainbow trout, common carp, European eel and Wels catfish (FishStatJ, 2017).

\section{European common carp market}

The European common carp market relies mainly on domestic production, but trade is going on mainly among the European countries and particularly still with live fish (Figures 5,6). The main importers of live carps are Poland, Germany and Romania, with 25\%, $21 \%$ and $12 \%$ of European import in 2013, respectively. Market with fresh chilled and frozen carps presents a minor part and includes some non-European countries. (FishStatJ, 2017).

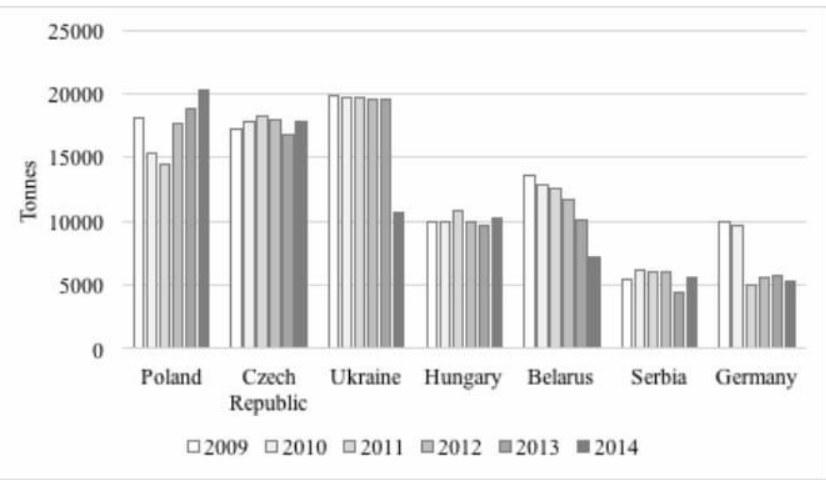

Figure 3: Common carp production in years 2009 - 2014 in countries with over 5000 tonnes production in 2014 (FishStatJ, 2017).

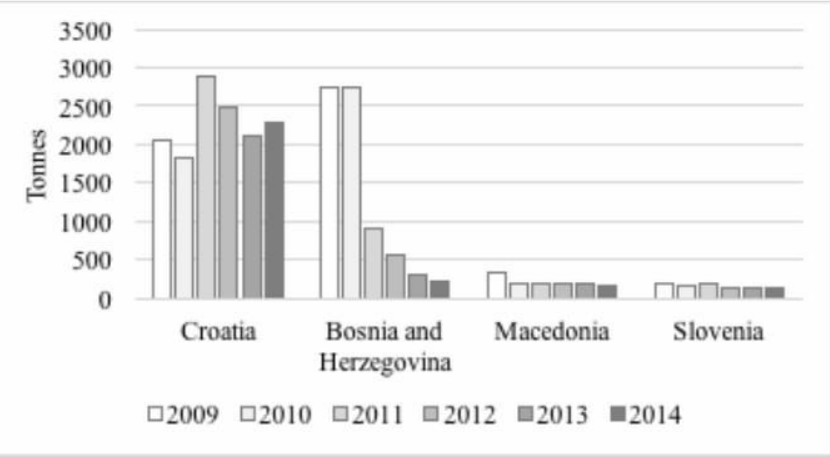

Figure 4: Common carp production in years 2009 - 2014 in Croatia and other countries of former Yugoslavia not presented in Figure 3 (FishStat,, 2017).

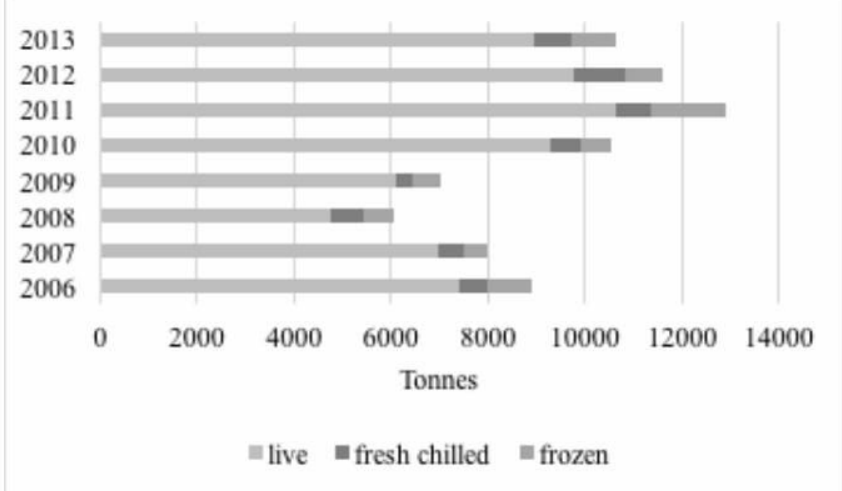

Figure 5: European import of common carp in years 2006 - 2013 (FishStat, 2017).

European export of common carp has not changed a lot recently (Figure 6). With more than $60 \%$ of export, the Czech Republic is the main exporter of carps in Europe, followed by Hungary, Lithuania, Croatia and Belarus with $5-10 \%$ of export (FishStatJ, 2017).

The majority of European carps are consumed locally, and reach a pick every year during its traditional use in Christmas time. However, the market offers variety of common carp meat products all over the year, but not all of them are well known to a wider population. 


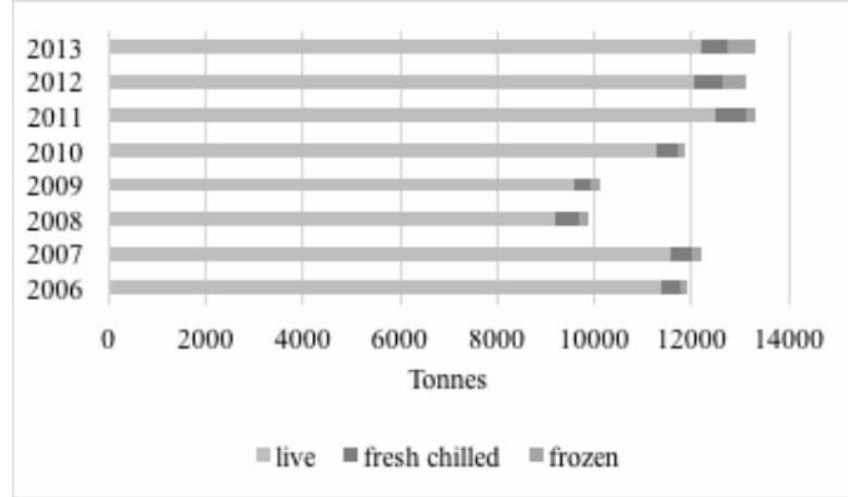

Figure 6: European export of common carp in 2006 - 2013 (FishStatJ, 2017).

Most common are the whole fish (Figure 7), but halves, steaks and fillets - fresh or frozen, are available as well. Fillets can also be prepared by smoking, marinating, or in terrines. On the market, there are also other products, like pate, salats, ham and jerky, or products that require some heat treatment, like sausages, polpettes and soups. Carp minced meat separated from the bones after filleting can also be used for replacing part of meat in traditional meat products (sausages, pates) in order to increase the levels of $n-3$ polyunsaturated fatty acids (PUFAs), eiocosapentaenoic acid (EPA) and docosahexaenoic acid (DHA) (Sampels et al., 2015).

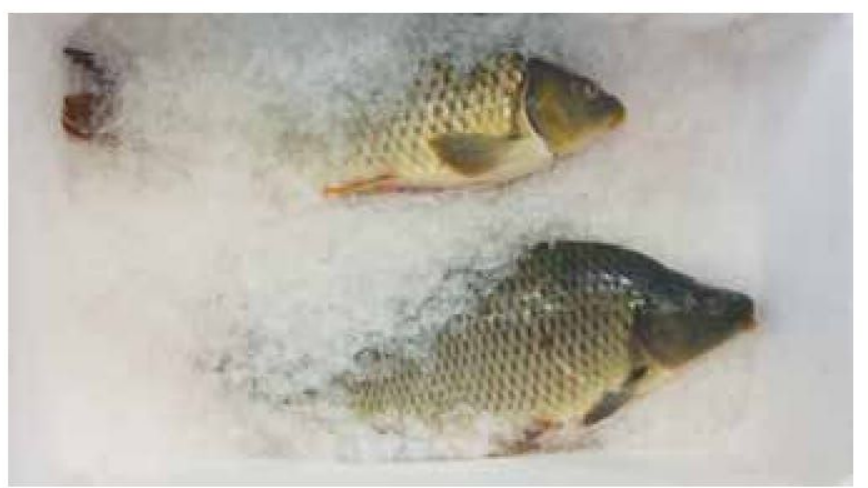

Figure 7: Whole chilled common carps (photo M. Sterniša, 2016). Nutritional value of common carp meat

\section{Nutritional value of common carp meat}

Fish are a great source of proteins, lipids, especially PUFAs, and micronutrients. Common carp muscle proximate composition is rather comparable to other fish, regularly available on our markets (Table 2). Carps protein value is slightly lower compared to trout, perch and sea bass. The main difference in protein value is between flatfish and salmon - in the case of the first, the carp has higher protein value and, in the case of the latter, it is lower. Salmon, as one of the most popular species in the global fish market stands out also because of the total lipid, total PUFAs, EPA, docosapentaenoic acid (DPA) and DHA values. The total lipid content of carp and trout is half as low as of salmon, while for total PUFAs the value is 2.5-times lower. Perch, sea bass and flatfish have much lower lipid content. With the exclusion of salmon, carp has the highest EPA content but lower DHA content compared to most other fish.

Table 2: Nutrient data on raw freshwater and marine fish meat per $100 \mathrm{~g}$ (USDA, 2015).

\begin{tabular}{|l|c|c|c|c|c|c|}
\hline & \multicolumn{3}{|c|}{ Freshwater fish } & \multicolumn{3}{|c|}{ Marine fish } \\
\hline & Carp & Trout & Perch & Sea bass & Flatfish & Salmon \\
\hline Water (g) & 76.31 & 73.80 & 79.13 & 78.27 & 84.63 & 64.89 \\
\hline Energy (kcal) & 127 & 141 & 91 & 97 & 70 & 208 \\
\hline Energy (k) & 531 & 589 & 381 & 406 & 294 & 871 \\
\hline Protein (g) & 17.83 & 19.94 & 19.39 & 18.43 & 12.41 & 20.42 \\
\hline Tryptophan (g) & 0.200 & 0.234 & 0.217 & 0.206 & 0.161 & 0.209 \\
\hline Threonine (g) & 0.782 & 0.915 & 0.850 & 0.808 & 0.585 & 0.860 \\
\hline Isoleucine (g) & 0.822 & 0.962 & 0.893 & 0.849 & 0.614 & 0.968 \\
\hline Leucine (g) & 1.449 & 1.696 & 1.576 & 1.498 & 1.087 & 1.615 \\
\hline Lysine (g) & 1.638 & 1.916 & 1.781 & 1.693 & 1.270 & 1.870 \\
\hline Methioine (g) & 0.528 & 0.618 & 0.574 & 0.546 & 0.455 & 0.626 \\
\hline Phenylalanine (g) & 0.696 & 0.815 & 0.757 & 0.720 & 0.508 & 0.846 \\
\hline Valine (g) & 0.919 & 1.075 & 0.999 & 0.950 & 0.651 & 1.107 \\
\hline Histidine (g) & 0.525 & 0.614 & 0.571 & 0.543 & 0.304 & 0.549 \\
\hline Total lipid (g) & 5.6 & 6.18 & 0.92 & 2.00 & 1.93 & 13.42 \\
\hline Total PUFAs (g) & 1.431 & 1.507 & 0.368 & 0.743 & 0.374 & 3.886 \\
\hline EPA (g) & 0.238 & 0.217 & 0.079 & 0.161 & 0.137 & 0.862 \\
\hline DPA (g) & 0.082 & 0.091 & 0.028 & 0.076 & 0.028 & 0.393 \\
\hline DHA (g) & 0.114 & 0.516 & 0.174 & 0.434 & 0.108 & 1.104 \\
\hline Ash (g) & 1.46 & 1.21 & 1.24 & 1.09 & 1.22 & 1.13 \\
\hline Iron - Fe (mg) & 1.24 & 0.31 & 0.9 & 0.29 & 0.18 & 0.34 \\
\hline Zinc-Zn (mg) & 1.48 & 0.45 & 1.11 & 0.40 & 0.32 & 0.36 \\
\hline Vitamin A (IU) & 30 & 280 & 30 & 154 & 33 & 193 \\
\hline (g) & & & & &
\end{tabular}

EPA - eiocosapentaenoic acid, DPA - docosapentaenoic acid, DHA - docosahexaenoic acid, PUFAs $-n-3$ polyunsaturated fatty acids

In 2010, EFSA published recommendations on dietary reference values for fats, which should represent 20 to $35 \%$ of energy intake. FAO and WHO (2011) expert group concluded that fish consumption is advantageous for growth and development of individuals, and that consumption of fish abundant in essential fatty acids reduces risk of coronary heart disease and stroke. PUFAs are essential nutrients and can not be synthesized in the human body. Therefore, body levels are influenced only by dietary intake. After ingestion, n-3 PUFAs are incorporated in tissue/cell membranes where they can modulate cellular signaling, membrane protein functions and gene expression (Surette, 2008, Mollace et al., 2013). An average daily intake of $250 \mathrm{mg}$ of EPA and DHA is recommended to reduce possibility for development of a cardiovascular disease. During pregnancy and lactation, additional 100 to $200 \mathrm{mg}$ of DHA positively influence on fetal development, and in children aged 6 to 24 months additional $100 \mathrm{mg}$ of DHA improve growth (EFSA, 2010). 
Beside being an excellent source of major nutrients (animal proteins and lipids), fish include also important bioactive micronutrients. According to WHO estimations (2000), more than 2 billion people worldwide are deficient in micronutrients, especially iodine, iron, zinc and vitamin A. Fish have been described as an unused source of micronutrients (Roos et al., 2007b; Bogard et al., 2017), since they contain macro- and microelements, especially sodium, potassium, calcium, iron, manganese, selenium and phosphorous, as well as vitamins (Roos et al., 2007a; Mohanty et al., 2016). Nutritional data (Table 2) reveal that common carp meat has the highest values for iron and zinc, but for vitamin A are considerably lower. Carp meat is also a good source of other micronutrients - calcium, magnesium, phosphorus, potassium, selenium, and vitamins (B complex, choline, D) (USDA, 2015).

Despite favourable nutritional composition of carp meat, various factors can influence the fat content and fatty acid composition of carp meat, especially carp nutrition (Mraz et al., 2012), purging (Zajic et al., 2013), processing and its final preparation (Sampels et al., 2014). One of the most often ways to prepare fish is by pan-frying. Sampels et al. (2014) studied common carp fillet changes caused by pan-frying and showed that it increases the fat content, in battered fillet more than in plain. Further, rapeseed oil compared to sunflower oil, butter and lard, was rated as the best for carp pan-frying, as it maintained the favourable $n-3 / n-6$ ratio without increasing saturated fatty acids. Interestingly, also oxidation was practically not detectable in fillets fried on rapeseed oil, as opposed to fillets fried in lard and sunflower oil (Sampels et al., 2014). The results additionally confirmed the previous reports, that fatty acid uptake in fish meat is negatively correlated with the raw fish content and positively correlated with fatty acid composition in the frying fat used (Mai et al., 1978; Weber et al., 2008; Sampels et al., 2014). We did not find any other studies investigating the effects of preparation on other nutrients in common carp.

\section{From research to a new product: omega-3 carp}

Common carp is the most important fish produced in Czech Republic. However, fish consumption, like in other countries, including most important common carp producers, is still limited to the traditional holiday time. With the aim to increase the consumption of fish meat, the research work on common carp rich in $n-3$ fatty acids was used to develop a new product. To ensure the production of carp meat rich in n-3 fatty acids a patented system for the aquaculture production of so-called omega-3 carp was developed and successfully tested (Mraz et al., 2011, Mraz et al., 2017). This type of omega-3 carp is on the market under a specific trademark (Figure 8).

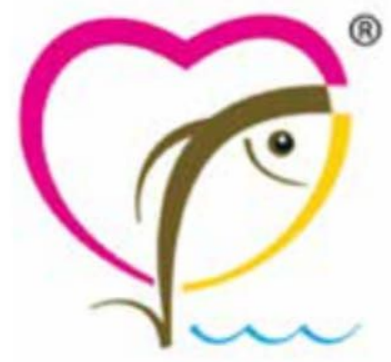

Figure 8: Trademark used in the Czech Republic for omega-3 carp (Mraz et al., 2017).

Lean and oily fish are a good source of n-3 PUFAs (Pickova and Morkore, 2007). Marine fish are usually known as a rich source of $n-3$ PUFAs, but recently also freshwater fish have gained importance as n-3 PUFAs dietary source and also common carp has been investigated for the potential of cardioprotective effect (Adamkova et al., 2011; Mraz et al., 2017). In these studies common carps with defined meat quality characteristics and high n-3 PUFAs levels were used (Mraz et al., 2012) which had almost five times the EPA and DHA content compared to the control group (Mraz et al., 2017). Diets enriched with $n-3$ common carp meat had great influence on plasma lipid parameters and inflammation markers in the secondary prevention of ischemic disease (Adamkova et al., 2011; Mraz et al., 2017). As such, common carp can be of major importance in combating metabolic disorders, especially in populations of regions without sea access.

\section{CONCLUSIONS}

The affordability and high nutritional value of food products are crucial facts for modern consumers. Common carp is an important fish in European aquaculture production, especially in Central and Eastern Europe with good natural resources for production. Thus, common carp indeed meets the above mentioned requirements, but it is often ignored because of its unattractive look. Beside this, many customers have experienced carp products of a low sensory quality and thus they believe that carp itself is a muddy and disgusting fish. However, this could be due to wrong production practices (e.g. short purging period) (Zajic et al., 2013) or mistakes in processing/supply chain (e.g. microbial activity) (Sterniša et al., 2016). In addition, accessibility of food products convenient for fast preparation, or ready-toeat products are prefered by consumers. Thus, more attention should be paid to the development of new products with positive impact on the fish freshness and shelf-life (Lunda et al., 2016). Much effort is needed also to improve marketing of carps products and knowledge transfer to the consumers. More research and inno- 


\section{Scientific and professional section}

vations should be supported and implemented in the area of production, processing and marketing to improve the whole supply chain of common carp and related products from the pond to the plate. This would give the opportunity to develop its potential better, since it is not fully exploited in many European countries including the main producing countries. In this way carp products of the highest quality could be delivered to the market in the attractive form for the consumer throughout the whole year.

\section{REFERENCES}

Adamkova, V., P. Kacer, J. Mraz, P. Suchanek, J. Pickova, I. Kralova Lesna, J. Skibova, P. Kozak, V. Maratka (2011): The consumption of the carp meat and plasma lipids in secondary prevention in the heart ischemic disease prevention. Neuroendocrinology Letters 32, Suppl. 2, 101-104.

Balon, E.K. (1995): Origin and domestication of the wild carp, Cyprinus carpio: from Roman gourments to the swimming flowers. Aquaculture 129, 3-48.

Bogard, J.R., S. Farook, G. C. Marks, J. Waid, B. Belton, M. Ali, K. Toufique, A. Mamun, S.H. Thilsted (2017): Higher fish but lower micronutrient intakes: Temporal changes in fish consumption from capture fisheries and aquaculture in Bangladesh. PLoS One 12, 4, e0175098.

European Food Safety Authority (EFSA) (2010): Scientific opinion on dietary reference values for fats, including saturated fatty acids, polyunsaturated fatty acids, monounsaturated fatty acids, trans fatty acids, and cholesterol. EFSA Journal 8, 3, 1461 1568.

Federation of Europeand Aquaculture Producers (FEAP) (2017): FEAP Annual Report 2017. Liege, Belgium.

FishStatJ - FAO Global Fishery and Aquaculture Statistics, Version 3.03. 2017.

Food and Agriculture Organization (FAO) (2016): FAO yearbook. Fishery and aquaculture statistics. Rome, Italy.

Food and Agriculture Organization (FAO) and World Health Organization (WHO) (2011): Report of the joint FAO - WHO expert consultation on the risk and benefits associated with fish consumption. FAO Fisheries and Aquaculture Technical Paper 978.

Lunda, R., Z. Linhartova, J. Masilko, P. Dvorak, S. Smole Možina, J. Mraz (2016): Effect of different types of descaling methods on shelf life of air-/vacuum-packaged common carp (cyprinus carpio L.) fillets under refrigerated storage conditions. Aquaculture International 24, 6, 1555-1568.

Mai, J., J. Shimp, J. Weihrauch, J.E. Kinsella (1978): Lipids of fish fillets changes following cooking by different methods. Journal of Food Science 43, 16691674.

Mohanty, B.P., T.V. Sankar, S. Ganguly, A. Mahanty, R. Anandan, K. Chakraborty, B.N. Paul, D. Sarma, J.S. Dayal, S. Mathew, K.K. Asha, T. Mitra, D. Karunakaran, S. Chanda, N. Shahi, P. Das, P. Das, M.S. Akhtar, P. Vijayagopal, N. Sridhar (2016): Micronutrient composition of 35 food fishes from India and their significance in human nutrition. Biological Trace Element Research 174, 2, 448-458.

Mollace, V., M. Gliozzi, C. Caresi, V. Musolino, F. Oppedisano (2013): Reassessing the mechanism of action of n-3 PUFAs. International Journal of Cardiology 170, 2, S8-S11.

Mraz, J., J. Pickova, P. Kozak (2011): Czech Patent nr. 302744. Feed for common carp and culture of common carp with increased content of omega-3 fatty acids.
Mraz, J., T. Zajic, J. Pickova (2012): Culture of common carp (Cyprinus carpio) with defined flesh quality for prevention of cardiovascular diseases using finishing feeding strategy. Neuroendocrinology Letters 33, Suppl. 2, 60-67.

Mraz, J., T. Zajic, P. Kozak, J. Pickova, P. Kacer, V. Adamek, I. Kralova Lesna, V. Lanska, V. Adamkova (2017): Intake of carp meat from two aquaculture production systems aimed at secondary prevention of ischemic heart disease - a follow-up study. Physiological Research 66, Suppl 1, S129-S137.

Pickova, J., T. Morkore (2007): Alternative oils in fish feeds. European Journal of Lipid Science and Technology 109, 256-263.

Roos, N., C. Chamnan, D. Loeung, J. Jakobsen, S.H. Thilsted (2007a): Freshwater fish as a dietary source of vitamin A in Cambodia. Food Chemistry 103, 4, 1104-1111.

Roos, N., M.A. Wahab, C. Chamnan, S.H. Thilsted (2007b): The role of fish in food-based strategies to combat vitamin $A$ and mineral deficiencies in developing countries. The Journal of Nutrition 137, 4, 1106-1109.

Sampels, S., T. Zajic, J. Mraz (2014): Effects of frying fat and preparation on carp (Cyprinus carpio) fillet lipid composition and oxidation. Czech Journal of Food Sciences 32, 493-502.

Sampels, S., T. Zajic, J. Mraz (2015): Increasing the omega-3 content of traditional meat products by the addition of an underutilized by-product from fish processing. Czech Journal of Food Sciences 33, 431-440.

Sterniša, M., J. Mraz, S. Smole Možina (2016): Microbiological aspects of common carp (Cyprinus carpio) and its processing - relevance for final product quality: a review. Aquaculture International 24, 6, 1569-1590.

Surette, M.E. (2008): The science behind dietary omega- 3 fatty acids. Canadian Medical Association Journal 178, 2, 177-180.

United States Department of Agriculture (USDA) (2015): USDA National Nutrient Database for Standard Reference, Release 28 (https://www.ars.usda.gov/ northeast-area/beltsville-md/beltsville-human-nutrition-research-center/nutrientdata-laboratory/docs/usda-national-nutrient-database-for-standard-reference/). Accessed online 9. July 2017.

Weber, J., V.C. Bochi, C.P. Ribeiro, A.D.M. Victorio, T. Emanuelli (2008): Effect of different cooking methods on the oxidation, proximate and fatty acid composition of silver catfish (Rhamida quelen) fillets. Food Chemistry 106, 140-146.

World Health Organization (WHO) (2000): World health report, 2000. Geneva, WHO.

Zajic, T., J. Mraz, S. Sampels, J. Pickova (2013): Fillet quality changes as a result of purging common carp (Cyprinus carpio L.) with special regard to weight loss and lipid profile. Aquaculture 400-401, 111-119.

Delivered: 15.6.2017.

Accepted: 8.8.2017. 


\section{Šaran - još neiskorišteni potencijal}

\section{SAŽETAK}

Šaran jejedna od najkultiviranijih riba u cijelom svijetu, a njegova proizvodnja stalno raste. Slatkovodna riba važan je izvor hrane u zemljama u razvoju, no u razvijenim zemljama riba se često smatra skupom delikatesom. Ne samo da je riba izvrsna i kvalitetna hranjiva namirnica (bjelančevine, lipidi, mikronutrijenti), ona uključuje i važne bioaktivne sastojke s blagotvornim učinkom na ljudsko zdravlje, od čega posebno n-3 višestruko nezasićene masne kiseline (PUFA) igraju važnu ulogu u sprečavanju kardiovaskularnih bolesti. Unatoč visokom sadržaju tih vrijednih nutrijenata, slatkovodna riba često je zanemarena kao njihov izvor. Međutim, proteklih godina i slatkovodna riba polako dobiva na važnosti kao hrana n-3 PUFA izvora. Tijekom proteklih godina, šaran je ispitivan sobzirom na mogući zaštitni učinakna srce, te je dokazano da meso šarana ima važne pozitivne učinke u prevenciji kardiovaskularnih bolesti i potrebno ga je priznati i promovirati kao zdravu hranu. Kako bi se mogli isporučiti proizvodi od šarana najviše moguće kvalitete, potrebno je na tom području provesti više istraživanja i inovacija radi poboljšanja cjelokupnog lanca proizvodnje od ribnjaka do tanjura.

Ključne riječi: šaran, proizvodnja u akvakulturi, hranjiva vrijednost, inovativni prehrambeni proizvodi

\section{Karpfen -vernachlässigte hochwertige Nährstoffquelle}

\section{ZUSAMMENFASSUNG}

Der Karpfen gehört zu den kultiviertesten Fischarten weltweit; seine Produktion steigt kontinuierlich an. Der Süßwasserfisch stellt eine bedeutende Nahrungsquelle in den Entwicklungsländern dar; in den entwickelten Ländern wird er aber häufig für eine teuere Delikatesse gehalten. Der Fisch ist nicht nur ein hervorragendes und äußerst nahrhaftes Nahrungsmittel (Eiweiße, Lipide, Mikronährstoffe), er enthält zudem wichtige bioaktive Inhaltsstoffe mit einer wohltuenden Wirkung auf die menschliche Gesundheit; dabei spielen insbesondere die $n-3$ mehrfach ungesättigten Fettsäuren (PUFA) eine bedeutende Rolle bei der Vorbeugung von Herz-Gefäßkrankheiten. Trotz dem hohen Gehalt an wertvollen Nährstoffen wird der Süßwasserfisch als eine bedeutende Nährstoffquelle sehr häufig vernachlässigt. Seit einigen Jahren kommt dem Süßwasserfisch als einer Quelle von $n-3$ mehrfach ungesättigten Fettsäuren eine immer größere Bedeutung zu. In den letzten Jahren wurde die mögliche Schutzwirkung des Karpfens aufdas Herz untersucht; dabei konnte nachgewiesen werden, dass das Karpfenfleisch zahlreiche positive Auswirkungen bei der Vorbeugung von Herz-Gefäßkrankheiten hat und es als gesunde Nahrung anerkannt und gefördert werden sollte. Um Karpfenprodukte mit bestmöglicher Qualität liefern zu können, bedarf es zahlreicher Untersuchungen und Innovationen zur Verbesserung der kompletten Produktionskette vom Fischteich bis zum Teller.

Schlüsselwörter: Der Karpfen, Produktion in der Aquakultur, Nährwert, innovative Lebensmittelprodukte

\section{La carpa - todavia potencial aún sin explotar}

\section{RESUMEN}

La carpa es uno de los peces más cultivados del mundo, y su producción está creciendo constantemente. Los peces de agua dulce son una fuente importante de alimentos en los países en desarrollo, pero en los paises desarrollados, el pescado se considera a menudo un manjar caro. Aparte de ser una excelente comida nutritiva de calidad (proteínas, lípidos, micronutrientes), incluye importantes ingredientes bioactivos que tienen un efecto beneficioso sobre la salud humana, de los cuales en especial los ácidos grasos poliinsaturados (PUFA) $n$-3 que tienen un papel importante en la prevención de enfermedades cardiovasculares. A pesar del alto contenido de estos valiosos nutrientes, los peces de agua dulce son a menudo descuidados como fuente de nutrientes. Sin embargo, en los años recientes los peces de agua dulce están adquiriendo importancia lentamente como alimentos fuente de PUFA n-3. En los últimos años, la carpa fue examinada con respecto al posible efecto protector sobre el corazón, y se ha demostrado que la carne de carpa tiene importantes efectos positivos en la prevención de enfermedades cardiovasculares y necesita ser reconocido y promovido como alimento saludable. Con el fin de ser capaces de ofrecer productos de carpa de la calidad más alta posible, es necesario en este área llevar a cabo más estudios e introducir innovaciones para mejorar toda la cadena de producción de la granja de peces hasta que llegan al plato.

Palabras claves: carpa, producción en acuicultura, valor nutricional, productos alimenticios innovadores

\section{La carpa - potenziale ancora non sfruttate}

\section{SUNTO}

L'allevamento della carpa è tra i più diffusi al mondo e la sua produzione è in costante aumento. Il pesce d'acqua dolce è un'importante fonte alimentare nei paesi in via di sviluppo; tuttavia, nei paesi più sviluppati, il pesce è spesso considerato, per il suo prezzo a volte proibitivo, un alimento per pochi. Il pesce non è soltanto un alimento straordinariamente nutriente (proteine, lipidi, micronutrienti): esso contiene anche importanti componenti bioattivi che svolgono un effetto benefico sulla salute umana, come, ad esempio, gli acidi grassi polinsaturi omega 3 (PUFA) che giocano un ruolo molto importante nella prevenzione delle malattie cardiovascolari. Malgrado siano ricchi di questi importanti nutrienti, i pesci d'acqua dolce spesso non sono sufficientemente apprezzati come loro fonte. Negli ultimi anni, tuttavia, anche i pesci d'acqua dolce sono riconosciuti come alimento ricco di acidi grassi polinsaturi omega 3. Negli ultimi anni, la carpa è stata sottoposta a prove di laboratorio finalizzate a provarne gli effettiprotettivi sul cuore; è stato cosi accertato che la carne della carpa svolge una funzione molto importante nella prevenzione delle malattie cardiovascolari e che va, quindi, riconosciuta e promossa come cibo salutare. Affinché la produzione ittica legata alla carpa sia della migliore qualità possibile, è necessario intensificare le ricerche e l'innovazione in questo settore al fine di migliorare l'intera catena produttiva dalla peschiera al piatto.

Parole chiave: carpa, produzione in acquacoltura, produzioni d'acquacoltura, valore nutritivo, prodotti alimentari innovativi 